\title{
Active labour market policy use in Luxembourg: evidence from a firm survey
}

Konstantinos Efstathiou ${ }^{2}$, Thomas Y. Mathä ${ }^{1}$, Cindy Veiga ${ }^{1}$ and Ladislav Wintr ${ }^{1 *}$ (i)

\begin{abstract}
We analyse the use of active labour market policy (ALMP) measures by Luxembourg firms during the years of economic and financial crisis (2008-2009) and the subsequent European sovereign debt crisis (2010-2013). About 34\% of Luxembourg firms used ALMPs between 2008 and 2013. Economy-wide, the use of ALMPs increased along both the extensive margin (more firms) and the intensive margin (more measures per firm). The likelihood that a firm hired with ALMPs is greater for firms that are large, multi-establishment, domestically oriented and firms facing strong demand and competition, with concerns about labour cost pressures.
\end{abstract}

Keywords: Firms, Survey, Crisis, Active labour market policy

JEL Classification: C25, J63, J68

\section{Introduction}

The main goal of active labour market policies (ALMPs) is to increase the employment opportunities for jobseekers and to improve matching between jobs (vacancies) and unemployed. ${ }^{1}$ In general, ALMPs include job search assistance measures, training programs and subsidised jobs. Unemployment benefits, youth apprenticeships and adult education measures are excluded. During the Great Recession unemployment in many European countries substantially increased and governments resorted to ALMPs to cushion the labour market outcomes of individuals out of work.

In Luxembourg, the Great Recession led to a sharp decline in real GDP in the initial phase $(-4.4 \%$ in 2009$)$. Unemployment rose from $4.0 \%$ in early 2008 to $5.7 \%$ by the end of 2009 and further to $7.1 \%$ in mid-2014. Thereafter, it receded slowly to $5.2 \%$ at the end of 2018. A broad range of labour market policies were introduced in Luxembourg to cushion the effects of the recession on the labour market. The government, for example, extended and scaled up short-time work (STW) provisions to encourage job retention for those firms experiencing temporary loss of demand. At its peak in spring 2009, $4.5 \%$ of employees used STW. ${ }^{2}$ Efstathiou et al. (2018, in this journal) study STW during the Great Recession in Luxembourg. In this paper, we focus on the remaining active labour market policy (ALMP) measures managed by the Luxembourg employment agency ADEM (Agence pour le Development de l'Emploi). During 2009-2014, the number of people involved in these ALMP measures rose continuously from about 3100 to 5000 (ADEM 2015), representing a rise of 0.4 percentage points to $1.3 \%$ of total employment.

The aim of this paper is to analyse the use of ADEM administered ALMP measures by Luxembourg firms during and after the Great Recession and their determinants using direct survey answers from CEOs and/or human resource managers. Hence, we analyse ALMPs from the firm perspective rather than the employee perspective. Despite their relevance, firm-level analyses on ALMPs are far less common in the economics literature. This paper is also the first ALMP study using firm-level data for Luxembourg. Zanardelli (2006) studied the effectiveness of Luxembourg ALMPs using employee data. More

\footnotetext{
*Correspondence: ladislav.wintr@bcl.lu

${ }^{1}$ Economics and Research Department, Banque Centrale du

Luxembourg, 2, Boulevard Royal, 2983 Luxembourg, Luxembourg

Full list of author information is available at the end of the article
}

\footnotetext{
${ }^{1}$ See European Commission (2016).

2 Total employees excluding agriculture and NACE2 sectors O-U.
} 
recently, Bia et al. (2018) evaluated the effect of language training programs for the unemployed in Luxembourg.

Our analysis is closely related to Bellmann and Stephan (2014, in this journal) who use German establishment data to study the association between firm-specific variables and the probability that a firm uses targeted wage subsidies. We extend their analysis and explicitly control for the effect of several different demand (both in level and volatility), supply and finance related shocks that firms may have experienced, as well as concerns about the costs and availability of labour with the required skills when hiring under permanent contract, the domestic orientation of firms and the share of cross-border workers. Owing to the large degree of internationalisation of the Luxembourg economy, immigrants and crossborder workers combined make up almost $75 \%$ of total employment.

Our main findings are as follows. About 34\% of Luxembourg firms used ALMPs to hire new employees in 2008-2013. On aggregate, ALMP use increased both on the extensive margin (more firms) and on the intensive margin (more measures per firm). The likelihood of using ALMPs is higher among firms that enjoy strong demand, are larger in size, domestically-oriented, face high competition and are concerned about high labour costs when hiring permanent employees. These results corroborate the main conclusions reported by Bellmann and Stephan (2014) for Germany.

The remainder of the paper is organised as follows. Section 2 reviews the related literature. Section 3 provides details on ALMPs administered by the public employment agency in Luxembourg. Section 4 presents the dataset. Sections 5 and 6 present the econometric estimation strategy and discuss the results. Section 7 concludes.

\section{Relevant literature}

The firm level determinants of participation in ALMPs have not been the subject of extensive research. To the best of our knowledge, only two papers focus directly on the link between structural firm characteristics and ALMP use. Bishop and Montgomery (1986) examine targeted employment subsidy programmes in the US, namely the Targeted Jobs Tax Credit (TJTC), the Work Incentive Program (WIN) tax credit and on-the-job training, as well as the Comprehensive Employment and Training Act (CETA). Their analysis is based on a sizestratified Department of Labor survey of employers. Using data from a multi-wave representative employer survey (the IAB Establishment Panel Survey), Bellmann and Stephan (2014) use German establishment data to study the association between firm-specific variables and the probability that a firm uses targeted wage subsidies.
Both papers confirm the importance of firm size, labour force turnover and other characteristics. However, no link is made between the economic situation faced by the firms and the probability they take up the wage subsidy. Using the information provided by the firm survey, we intend to fill this gap.

Since most of the ALMPs included in the survey require that the hire be made through ADEM, firm recruitment practices may determine firm take-up of ALMP measures. Recruitment channels can be broadly divided into informal (private or social networks) and formal (posting vacancies at the employment agency, advertisements). Of course, recruitment strategies may be more complex, involving more than one channel and/or instrument. For instance, employers may vary their search along the extensive margin (number of candidates) or the intensive margin (time per candidate), across channels or even vacancies, depending on the characteristics of the job. Many studies have attempted to provide theoretical explanations of how firms choose recruitment channels and underpin these theories with empirical support. The literature generally agrees that employers select one or more channels to fill a vacant post with the objective of minimizing the total costs linked to the process of hiring subject to its associated benefit. Costs comprise (i) direct costs, including resources devoted by the firm to generate a flow of applicants and collect relevant information and (ii) indirect costs, including the opportunity cost of keeping the job unfilled until a suitable candidate is found. Benefits accrue to the firm from the productivity obtained from the match between the position and the selected worker. Below, we briefly present the firm characteristics the literature generally associates with a higher probability of using the employment agency to fill positions.

First, a strong and robust association has been found between firm size and use of ALMP subsidies to hiring. However, the literature is far from unanimous about the exact mechanism governing this link. Bishop and Montgomery (1986) found that large U.S. firms were more likely to use (and know about) employment/training programmes. They advanced three explanations: (a) participation involves fixed costs, so average cost per new hire is lower for large firms; (b) larger firms generate larger job applicant pools, increasing the probability of a match with an eligible jobseeker; (c) if matching with targeted jobseekers is a risky investment, the costs of mistakes are more severe for smaller firms. Bellmann and Stephan (2014) support this finding using German firm data and conjecture that it reflects familiarity with subsidy programmes among large firms' human resource departments, a hypothesis also advanced by Bishop and Montgomery (1986). A closely related idea is that firms 
with multiple establishments can spread the fixed costs of participation and will therefore find it less costly overall (Bishop and Kang, 1991). Bellmann and Stephan (2014) also link firm size to possible hiring mistakes-but in the reverse direction: Employment Protection Legislation (EPL) raises firing costs for larger firms, providing them with an incentive to use hiring subsidies as insurance.

The recruitment literature also provides some necessary intuitions. The public employment agency provides a flow of applications and a first screening device at no cost to the employer, who subsequently incurs the cost of interviewing the applicants. Barron and Mellow (1982) suggest that firms with a low unit cost of interviewing will benefit most from a costless flow of applicants, so long as it compensates for the higher indirect costs resulting from the lower probability of finding an acceptable candidate (assuming lower quality on average). According to Barron and Mellow (1982), large firms are more likely to enjoy this comparative advantage because of increased specialisation within the firm. Indeed, Barron, Bishop and Dunkelberg (1985) found that firm size was associated with larger numbers of applicants interviewed (extensive search) and more hours spent on each interviewed applicant (intensive search). Measures of employer search were obtained from the Employer Opportunity Pilot Project survey of employers. In a similar vein, Welters and Muysken (2006) maintain that regardless of their size, multi-establishment firms face lower direct costs because they can share expertise across establishments and enjoy economies of scale. The authors used a dataset of a study on the employment effects of a Dutch employment subsidy scheme conducted in 1999 by the Netherlands Economic Institute (NEI). ${ }^{3}$

The skills required for the job are also likely to determine whether the employment agency is involved. Assuming that the productivity of a match is positively correlated with the level of required skills, the indirect cost of an unfilled high-skilled vacancy is higher for positions requiring more skills. However, the cost of a bad match is also expected to be larger for positions requiring more skills, which provides an incentive for more intensive search and, as a result, longer selection periods. Using Dutch survey data on vacancies, Van Ours and Ridder (1993) estimate that selection periods tend to increase with the level of education and experience required for a given vacancy. Using microdata on vacancies in order to examine employers' search behaviour in the Dutch labour market, Gorter et al. (1996) also find that jobs that require higher education levels take longer to fill through most recruitment channels. In any case, longer and more intensive search

${ }^{3}$ Van Polanen Petel et al. (1999). periods will usually be required to reduce the probability of a bad match when using the employment agency instead of alternative recruitment channels. Indeed, Van Ours (1994) finds that vacancies requiring secondary or higher education level carry significantly lower hazard rates (longer duration) when filled through the public employment office. This may be expected since the distribution of jobseekers within the employment agency (registered unemployed) may be thinner on the high-skill end and because it may be rational for firms to increase their search effort to counter real or perceived "stigma" effects of unemployment on candidate productivity. Therefore, vacancies posted and filled through the employment agency are more likely to be for low-skill positions.

Collective pay agreements may also determine whether firms use ALMPs, even though the empirical evidence remains inconclusive about the direction as well as the significance of the effect. Bellmann and Stephan (2014) analyse hiring subsidies for hard-to-place jobseekers in the absence of deadweight loss, i.e. assuming that firms taking-up the ALMPs would otherwise not have hired the eligible jobseeker. Gerlach et al. (2008) use survey data to show that collective pay agreements usually include a fairness principle, which means they are not flexible enough to allow for the comparatively lower productivity of these new hires. This suggests ALMPs are likely to be more attractive for employers with collective pay agreements. However, Bellmann and Stephan (2014) find that collective pay agreements at both firm and industry level are associated with a lower probability of using wage subsidies. Bishop and Montgomery (1986) suggest that union coverage will raise the costs of dismissal when bad matches are formed and therefore will discourage firms from hiring jobseekers targeted by ALMPs. Thus, these authors expect the share of unionised workers to be negatively related to participation, but the estimated coefficients are not significant.

Finally, Bellmann and Stephan (2014) find that the share of fixed-term (temporary) workers appears to have a positive effect on the probability of using a targeted employment subsidy. In addition, Van Ours (1994) and Gorter et al. (1996) find that public employment agencies fill temporary jobs significantly faster than permanent jobs.

\section{ALMPs in Luxembourg}

\subsection{Main characteristics}

ALMPs aim to improve the functioning of the labour market and are directed at the unemployed. In contrast to passive policy (i.e. income support, unemployment benefits), these measures include: (i) job brokering, (ii) training and (iii) direct job creation through subsidies for jobs or public sector employment (Calmfors 1994). Most ALMPs examined in the survey are aimed at employment creation, subsidising the labour cost of hires from targeted 
Table 1 Main ALMP measures in Luxembourg

\begin{tabular}{|c|c|c|c|c|}
\hline \multirow{2}{*}{$\begin{array}{l}\text { ALMP managed by national employment } \\
\text { agency ADEM }\end{array}$} & \multirow[t]{2}{*}{ Description } & \multicolumn{3}{|c|}{ Take-up rate, $\%$} \\
\hline & & $2008-2009$ & 2010-2013 & 2008-2013 \\
\hline Financial aid to hire older long-term unemployed & $\begin{array}{l}\text { Social security subsidy for hiring long-term registered } \\
\text { unemployed aged }>30\end{array}$ & 8.7 & 13.1 & 16.1 \\
\hline Re-employment support & $\begin{array}{l}\text { Partial subsidy of the differential between current } \\
\text { and previous wage for registered unemployed and } \\
\text { employees made redundant }\end{array}$ & 7.0 & 12.5 & 14.8 \\
\hline Tax-relief for hiring an unemployed person & $\begin{array}{l}\text { Tax credit for hiring registered unemployed assigned by } \\
\text { ADEM's placement service }\end{array}$ & 8.0 & 9.9 & 13.3 \\
\hline Apprenticeship subsidies & $\begin{array}{l}\text { Subsidisation of apprenticeship fees and social security } \\
\text { contributions }\end{array}$ & 11.0 & 9.6 & 14.7 \\
\hline Employment initiation contract & $\begin{array}{l}\text { Contract for young jobseekers including on-the-job } \\
\text { training and subsidizing salary and social security } \\
\text { contributions }\end{array}$ & 4.3 & 5.7 & 7.5 \\
\hline \multicolumn{2}{|c|}{ At least one ALMP managed by national employment agency ADEM } & 22.7 & 24.9 & 33.6 \\
\hline
\end{tabular}

Weighted to be representative of firm population. Sample size $n=631$. Excludes firms with only partial information on the use of individual ALMP measures for either of the sub-periods. Excludes the category "Other measures"

groups (e.g. young, older or long-term unemployed). Typically, they subsidise employers directly (wage, social security contributions) or indirectly (tax credit) when hiring a jobseeker belonging to the targeted pool. In Luxembourg, most of these measures are administered by the employment agency and require employers to file a claim. Some measures even require that ADEM's placement service performs the match between a registered jobseeker and a posted vacancy. Some of these ALMPs were either introduced or scaled up during the crisis.

In the questionnaire, firms were asked whether they used any of the following ALMP measures in two different sub-periods (2008-2009 and 2010-2013):

1. Financial aid to hire older workers or long-term unemployed,

2. Re-employment support,

3. Tax relief for hiring an unemployed person,

4. Apprenticeships subsidies,

5. Employment initiation contract (CIE),

Table 1 briefly describes these measures and reports the share of firms using them (take-up rate). ${ }^{4}$

\footnotetext{
${ }^{4}$ We focus on ALMP measures managed by ADEM. The survey questionnaire contained two more measures the (i) work-lending facility and (ii) deduction of relocation expenses for highly skilled workers from abroad. These measures do not fall under the "narrow" definition of ALMPs in Calmfors (1994). In Luxembourg, these measures are not managed by ADEM because they are not addressed to the unemployed. Our survey results indicate that few firms in Luxembourg used these measures during 2008-2013, so the remaining analysis is limited to ALMP by ADEM. The work-lending facility was used by $1.7 \%$ of firms in $2008-2009$ (3.1\% in 2010-2013). The deduction of relocation expenses for highly skilled workers from abroad was used by $0.9 \%$ of firms in $2008-2009$ (1.4\% in 2010-2013).
}

These ALMP measures differ according to the jobseekers' eligibility criteria, the employers' entitlement criteria and the type and maximum duration of the subsidy. These measures often impose complex conditions to ensure they target hard-to-place and/or vulnerable groups while limiting the deadweight loss resulting from granting subsidies for new hires that would have being hired irrespectively of receiving the subsidy (Table 2).

\subsection{Jobseeker eligibility}

Most ALMPs managed by the employment agency ADEM apply only to registered, i.e. unemployed, jobseekers. The only exceptions are re-employment support, which can also be claimed by employees who were fired or quit and apprenticeship subsidies, which only require a signature of an apprenticeship contract. All other measures are limited to jobseekers that meet a combination of age and unemployment duration criteria. In fact, financial aid for hiring long-term or older jobseekers employs a mixed criterion for three distinct age groups, with the required unemployment duration falling as the age cutoff increases. An additional condition applicable for tax relief only is that the registered jobseeker be assigned by ADEM's placement service. Finally, unlike all other ALMPs, re-employment support is not claimed by the firm but by the jobseeker.

The vast majority of the registered unemployed are Luxembourg residents, but non-resident cross-border commuters constitute a large part of salaried employment in the country. Therefore, firm hiring patterns may determine the type of firms that benefit from ALMPs. According to data from Réseau d'Etudes du Marché $d u$ 
Table 2 Characteristics of ALMP measures (managed by ADEM) ${ }^{\mathrm{a}}$

\begin{tabular}{|c|c|c|c|c|c|c|c|c|c|}
\hline \multirow[t]{2}{*}{ ALMP } & \multicolumn{2}{|l|}{ Restrictions } & \multirow[b]{2}{*}{$\begin{array}{l}\text { Unemployment } \\
\text { duration } \\
\text { (months) }\end{array}$} & \multirow[b]{2}{*}{ Age (years) } & \multicolumn{3}{|l|}{ Type } & \multirow{2}{*}{$\begin{array}{l}\text { Maximum } \\
\text { duration } \\
\text { (months) }\end{array}$} & \multirow[t]{2}{*}{ Claimed by } \\
\hline & Registered & Assigned & & & Compensation & $\begin{array}{l}\text { Social } \\
\text { security }\end{array}$ & Tax credit & & \\
\hline \multirow{3}{*}{$\begin{array}{l}\text { Financial } \\
\text { aid to hire } \\
\text { long-term/ } \\
\text { older unem- } \\
\text { ployed }\end{array}$} & $x$ & & $>12$ & $>30$ & & $x$ & & 24 & Employer \\
\hline & $x$ & & $>3$ & $>40$ & & $x$ & & 36 & Employer \\
\hline & $x$ & & $>1$ & $>45$ & & $x$ & & $\begin{array}{l}\text { Up to retire- } \\
\text { ment }\end{array}$ & Employer \\
\hline $\begin{array}{l}\text { Re-employ- } \\
\text { ment sup- } \\
\text { port }\end{array}$ & & & & & $x$ & & & 48 & Jobseeker \\
\hline $\begin{array}{l}\text { Tax relief for } \\
\text { hiring an } \\
\text { unem- } \\
\text { ployed }\end{array}$ & $x$ & $x$ & $>3$ & & & & $x$ & 36 & Employer \\
\hline $\begin{array}{l}\text { Appren- } \\
\text { ticeship } \\
\text { subsidies }\end{array}$ & \multicolumn{2}{|c|}{ Apprenticeship } & & & $x$ & $x$ & & & Employer \\
\hline $\begin{array}{l}\text { Employment } \\
\text { initiation } \\
\text { contract }\end{array}$ & $x$ & & $>3$ & $<30$ & $x$ & $x$ & & 18 & Contract \\
\hline
\end{tabular}

ADEM; publicly available information from: http://www.adem.public.lu/fr/index.html

a This list does not include the ALMPs financed via the European Social Fund (ESF) Projects. The latter represent only a small portion of the measures implemented in Luxembourg. These projects include e.g. training programs designed specifically for certain positions or branches (e.g. Fit4Entrepreneurship promoting entrepreneurship, Fit4CodingJobs training web and mobile developers, Fit4Green\&BuildJobs in the construction sector, Fit4FinancialMarkets in the financial sector etc.). Please refer to http://www.fonds-europeens.public.lu/fr/fonds-europeens/fse/index.html for further information

Travail et de l'Emploi Luxembourgeois (RETEL), ${ }^{5}$ the cumulated flow of new hires from March 2014 to March 2015 represented $27 \%$ of the stock of jobs at the end of that period. ${ }^{6}$ Focussing on resident jobseekers, the cumulated flow of new hires represented $30 \%$ of the stock of jobs occupied by resident employees. ${ }^{7}$ For that period, the ratio of cumulated new hires to the stock of jobs was highest in business services (36\% for residents) and lowest in manufacturing (19\% for residents). The share of residents (as opposed to cross-border workers) in total hires and in total employment is also the highest in business services and the lowest in manufacturing.

\subsection{Type of subsidy}

Almost all of the ALMPs considered involve full subsidy of social security contributions paid by the employer. ALMPs differ in the duration of this subsidy. However, the re-employment support consists of a (monthly)

\footnotetext{
${ }^{5}$ The underlying data can be found here: http://adem.public.lu/fr/march e-emploi-luxembourg/faits-et-chiffres/statistiques/igss/Tableaux-de-bord/ index.html).

${ }^{6}$ RETEL, excluding agency workers (intérimaires) hires and employment; NACE C, F, G, H-N.

7 The cumulated flow of terminated contracts over this period represented $28 \%$ of the stock of jobs occupied by residents (i.e. net job creation was $2 \%$ ).
}

compensation subsidy, amounting to the difference between $90 \%$ of the employee's previous compensation and his/her current compensation. For this subsidy, previous compensation is capped at 3.5 times the social minimum wage for the unskilled, thus indirectly targeting a more vulnerable group within the unemployed. The tax credit for hiring an unemployed jobseeker assigned by ADEM is equal to $15 \%$ of the deductible amount of gross pay (over a maximum duration of 36 months). Apprenticeship subsidies reimburse the employer for either $27 \%$ or $40 \%$ of the legally mandated compensation over the whole apprenticeship, depending on the traineeship diploma conferred. Finally, the employment initiation contract (CIE) involves a subsidy covering $50-65 \%$ of the new hire's base salary for the first 12 months. If a contract extension for an additional 6 months is granted, the subsidy falls to $30 \%$.

\subsection{Employer/vacancy eligibility}

To qualify for the subsidy, employers are required to post a vacancy with ADEM and fill it with an eligible jobseeker found through ADEM. Luxembourg law requires employers to report all vacancies to ADEM, but in practice this obligation is not always respected. This means that labour market matches are usually formed by jobseekers and employers through other recruitment 
channels, such as advertisements or informal networks, and therefore do not qualify for the subsidies, although they would in principle be eligible except that they were not made through ADEM. This means that the numbers on new hires account for more than the flow of vacancies filled through ADEM.

\subsection{ALMPs during 2008-2013}

Finally, it should be noted that all but one ALMP measure had been created before 2008 and none of them was significantly changed during the crisis or its aftermath. The only exception is the employment initiation contract, CIE, which was implemented in July 2007 and temporarily modified from November 2009 to December 2010 to also cover qualified young jobseekers (previously excluded). This temporary modification was extended twice until December 2012 and became permanent in April 2013. It replaced two other measures, the CAT (contrat d'auxiliaires temporaries) privé and SIE (stage d'insertion en enterprise), which Zanardelli et al. (2006) found effective in raising employment prospects, especially in the short-run. However, in France a similar policy aiming to integrate young dropouts, the Contrat Jeune en Enterprise (CJE), seems to have been less successful (Roger \& Zamora, 2011). In fact, this particular French ALMP was discontinued in 2008. Using administrative data, Bia et al. (2018) show that language training programs increase the re-employment probability of unemployed people in Luxembourg but has not effect on their wages.

The number and share of jobseekers eligible for hire with the assistance of ALMPs rose after the onset of the crisis. In particular, the national unemployment rate increased from $4 \%$ in 2008Q4 to 7\% in 2013Q4. Average unemployment duration also increased, with the long-term unemployed ( $>12$ months) making up $45 \%$ of the unemployed in 2013Q4, as opposed to only $35 \%$ in 2008Q4. The number of low-skilled unemployed also increased and their composition shifted to older age $(50>)$ and longer duration. ${ }^{8}$ The trend towards long-term unemployment increased the take-up rate of financial aid for older/long-term unemployed. The temporary widening of the CIE (up to the end of 2012) also increased the number of participants.

\section{Data}

To analyse the use of ALMPs in Luxembourg, we draw on a survey on the labour market adjustment of firms during 2008-2013 in Luxembourg. ${ }^{9}$ The survey asked

\footnotetext{
${ }^{8}$ See BCL (2015).

9 The same dataset is used by Efstathiou et al. (2018) to study STW in Luxembourg.
}

firms in Luxembourg detailed questions about company characteristics, how they were affected by the crisis and how shocks and changes in the economic environment led them to adjust labour, wages and prices. The survey provides information on firms' perceived external factors related to the economic crisis to affect their activity, specifically the level of demand, demand volatility, access to finance, customers' ability to pay and availability of supplies. While at the aggregate level Luxembourg went through a deep recession in 2008-2009, the disaggregate data from the survey provides a more differentiated picture, as firms experienced both positive and negative shocks. For example, 36\% (41\%) firms ${ }^{10}$ experienced negative demand shocks during 2008-2009 (2010-2013) while, at the same time, $26 \%$ (35\%) reported that demand positively affected their activity during these two respective sub-periods (see also Mathä et al. 2016 for details).

The survey also included a set of questions on the public employment support measures introduced by the government of Luxembourg. Most questions refer to two separate time periods; the years 2008-2009 cover the initial phase of the economic and financial crisis while the years 2010-2013 capture the European sovereign debt crisis.

The sample is derived from a target population of firms based on the Luxembourg firm register at the end of 2013. It covers firms in operation since end-2007 in the sectors: manufacturing (NACE2: C), construction (NACE2: F), wholesale and retail trade (NACE2: G), business services (NACE2: H, I, J, L, M, N) and financial services (NACE2: K) and the size classes: "1-4 employees" (micro firms), "5-19 employees" (very small firms), "20-49 employees" (small firms), "50-199 employees" (medium-sized firms) and "200+employees" (large firms). The final sample contains 674 firms. The sample is post-stratified so that results are representative of either the target population of firms or the set of employees in the target firm population. For a detailed description of the survey, including the questionnaire, field phase, sampling, weighting and basic structural characteristics, please see Mathä et al. (2016).

\section{Regression specification and variables}

To analyse firms' decision whether to take up ALMP measures, we model the likelihood of firm participation as a function of external factors affecting firm activity (i.e. the shocks) as well as structural firm characteristics. We pool the 2008-2009 and 2010-2013 sub-periods into

\footnotetext{
${ }^{10}$ In employment weighted terms in private sector employment excluding agriculture and energy.
} 
one regression to increase the number of observations. ${ }^{11}$ The dependent variable refers to a binary choice variable taking the value 1 if the firm uses ALMP measure(s) in period $t$ and 0 otherwise. Assume that the observed answer in the survey is related to the continuous latent variable $y^{*}$ according to the following mapping:

$$
y_{i t}=\left\{\begin{array}{ll}
0[\text { no measure used }] & \text { if } y_{i t}^{*} \leq 0 \\
1[\text { ALMP measure(s) used }] & \text { if } y_{i t}^{*}>0
\end{array} .\right.
$$

We estimate a logit model with

$$
\operatorname{Prob}\left[y_{i t}=1\right]=\frac{\exp \left(x_{i t} \beta+\varepsilon_{i t}\right)}{1+\exp \left(x_{i t} \beta+\varepsilon_{i t}\right)}
$$

where $\varepsilon_{i t}$ is the independently distributed error term. ${ }^{12}$ The set of covariates includes mainly variables related to the economic crisis and structural firm characteristics.

The survey does not discriminate between firms that regularly post vacancies with ADEM and firms that only use alternative recruitment channels. Therefore, in the observed data, the determinants of using the employment agency cannot be isolated from the determinants of taking up ALMP subsidies. In other words, the take-up variable cannot be conditioned on the use of ADEM as a recruitment channel. All we can estimate is the likelihood that a firm hired through ADEM and claimed a subsidy. Whether a firm hires via ADEM does not affect our results since we can reasonably assume that all Luxembourg firms are aware of the existence of ADEM and ALMPs in general. In other words, we assume that firms that were hiring at least implicitly considered the measures offered by ADEM. ${ }^{13}$

\subsection{Shock variables}

The questions in the survey are phrased neutrally, i.e. how factors such as the level of demand affected the firm's activity in period $t$. The answer categories are formatted along a Likert scale ranging from 1 to 5 , which we subsequently re-scaled and centred as follows: strong decrease $(-2)$, moderate decrease $(-1)$, unchanged $(0)$, moderate increase $(+1)$ and strong increase $(+2)$. Given the ordinal nature of the answers, various specifications were tried to assess the validity of various parameter restrictions, i.e.

\footnotetext{
${ }^{11}$ As a robustness check, we considered a random effects specification, see robustness section.

12 The dataset contains one observation for each firm and sub-period (although many covariates are reported only once and are therefore timeinvariant, see Table 5). Therefore, we cluster the standard errors at the firm level to allow the error term for each firm to be correlated across the two sub-periods.

${ }^{13}$ In the robustness section, we briefly discuss a specification that includes a dummy variable taking the value of 1 if there is an ADEM agency in the town of the firms.
}

(not) assuming the probability to be linearly increasing in the ordinal scale, merging answers indicating increases/ decreases or restricting attention to strong changes only. Thus depending on the specification, the reference category is firms that experienced no effects on their activity or firms that experienced no or only moderate effects.

\subsection{Firm characteristics}

Firm size is taken into account through the dummy variables indicating the size class. The base category is firms employing 1-4 employees, complemented by classes for 5-19, 20-49, 50-199 and 200+employees. Since we expect that collective pay agreements might matter, we also include a dummy variable if a collective pay agreement of any kind (firm-level or outside the firm) was applied in 2013.

Firm-specific variables include the share of permanent full-time employees and the share of permanent part-time employees in 2007. The share of fixed-term/temporary employees in that same year serves as base category. As described in Sect. 2, Bellmann and Stephan (2014) found that temporary jobs are filled more easily by the public employment agency, which increases the likelihood of using ALMP employment subsidies. Therefore, we expect a negative marginal effect from these two regressors. We also include the share of employees with a tenure status exceeding 5 years to capture the extent of labour turnover during 2008-13. Since in Luxembourg a large share of employees is resident abroad, we also expect firms with higher shares of cross-border employees to be less likely to hire under ALMPs. This reflects ADEM's role as a national institution focussed on resident jobseekers eligible for unemployment benefits. Cross-border workers who lose their job in Luxembourg are supposed to register with their respective national employment agency. ${ }^{14}$ We do not have information on the composition of firms' labour force by education or previous work experience, but the questionnaire did ask firms to report the shares of skilled and unskilled, manual and non-manual employees in 2013 using the ISCO-08 classification. We included the share of skilled employees (manual and non-manual) and expect the corresponding marginal effect to be negative as found in the literature. ${ }^{15}$

Finally, we control for the firm's sector of activity. The preceding tables suggested heterogeneous firm

\footnotetext{
${ }^{14}$ Since May 2012, non-residents who lose their job in Luxembourg may also register at ADEM (in addition to their country of residence) to access job vacancies posted at ADEM and some active labour market measures, e.g. the re-employment support measure. These non-resident jobseekers are not eligible for unemployment benefits in Luxembourg

15 More than half the unemployed registered at the ADEM have a low educational level (45\% primary education only, $11 \%$ lower secondary education).
} 
participation across sectors. In the logit model, we identify the effect of economic disturbances, firm and labour force characteristics after accounting for differences across economic sectors. We also include a set of structural firm-level controls such as whether the firm is a multi-establishment firm, which we expect to be positively related to ALMP use. Furthermore, we include dummy indicators showing whether the firm is headquartered in Luxembourg ('affiliate/subsidiary'), is under domestic control ('domestic ownership'), and the share of domestic revenue in total revenue. The latter three variables capture, loosely speaking, the 'domestic orientation' of the firm. We conjecture that more domestically-oriented firms are more likely to use AMLPs, as they are better connected with the Luxembourg labour market institutions and economy. The variables cost of labour and availability of skilled labour capture firms' concerns to hire employees under permanent contract. Firms reporting that high wages are an obstacle to hire permanent employees are more likely to resort to ALMP use, as this effectively lowers their labour cost (at least temporarily). Similarly, firms with concerns about the unavailability of skilled labour are expected to be more likely to use ALMPs. For example, firms not being able to find skilled labour on the market invest in training their new hires until their productivity matches their wage. The final control variable is measure of the severity of competition on the product market.

\section{Estimation results}

Table 3 reports the estimated marginal effects from three different pooled logit specifications with different definitions of the shock variables, as discussed in Sect. 5 . Starting with external factors, only demand-related shocks have a consistent, statistically significant impact on ALMP participation. In particular, a demand-driven increase in activity is associated with an increase in the probability of using ALMPs. The size of this positive shock also seems to matter. In specification (2), demand shocks that strongly boost activity increase the probability of take-up by more than demand shocks that boost firm activity moderately. In addition to changes in the level of demand, its volatility/uncertainty also appears to play a statistically significant role in firm decisions to use ALMPs. The probability of participation increases for firms reporting a negative effect of demand volatility/uncertainty on their activity. This particular result is however driven by non-growing firms (in terms of employment) in the sample (about 390). Restricting the analysis to growing firms, i.e. firms that have increased their number of employees between the end of 2007 and 2013, shows no statistical difference in the likelihood of using ALMPs for firms reporting negative impact of demand volatility/uncertainty and the remaining ones (see Sect. 6.1 of estimates and Table 7 in Appendix 2). Firms reporting a positive effect of demand volatility/uncertainty on their activity are more likely to use ALMPs both in Tables 3 and 7.

Turning to firm characteristics, firms facing severe competition and firms with labour cost pressures have a significantly higher probability of using ALMPs, as is expected. In addition, larger firms have a higher probability of using a ALMPs, even after controlling for other factors. The effect increases with size class (except for the largest size class), in line with the theoretical predictions. Multiple establishment firms are more likely to hire under ALMPs, consistent with the conjecture by Bishop and Kang (1991) that they are able to spread the fixed costs of participation across establishments. In terms of sectors, even controlling for other factors, firms in business services, manufacturing and financial intermediation appear to be significantly less likely to use ALMPs than firms in the trade sector. A similar finding is reported by Bellmann and Stephan (2014). Once we control for the economic environment and differences in firm characteristics, trade firms tend to have a higher likelihood of using ALMPs than firms in financial intermediation, business services or manufacturing. Lastly, no robust significant effect is found for the application of a collective pay agreement.

The results suggest that affiliates and subsidiaries have a significantly lower tendency to use ALMPs, possibly reflecting that hiring decisions are taken at parent level. The marginal effects for the share of domestic revenue in total revenue and for domestic ownership are both positive but only the former is statistically significant. Taken together, these results may indicate greater importance of ALMPs for domestically-oriented firms.

Regarding the composition of firms' workforce the estimated probability is not statistically different for firms with higher shares of permanent employees, be it for permanent or part-time employees. There is no indication that firms with larger share of temporary workers have higher propensity to hire ALMP eligible jobseekers recruited through ADEM. A very robust result across various specifications is the negative marginal effect of the share of cross-border workers on the probability of using ALMPs. To the extent that the existing cross-border worker share is a reflection of a firm's propensity to hire non-resident workers, this result is logical. Crossborder workers represent a large fraction of employment in Luxembourg but are much less likely to be registered with ADEM and therefore will not be eligible for ALMPs. The share of high-skill employees is not statistically significant, possibly indicating that firms recruit for highskilled positions using channels other than ADEM. 
Table 3 Pooled logit estimates for probability of using ALMPs

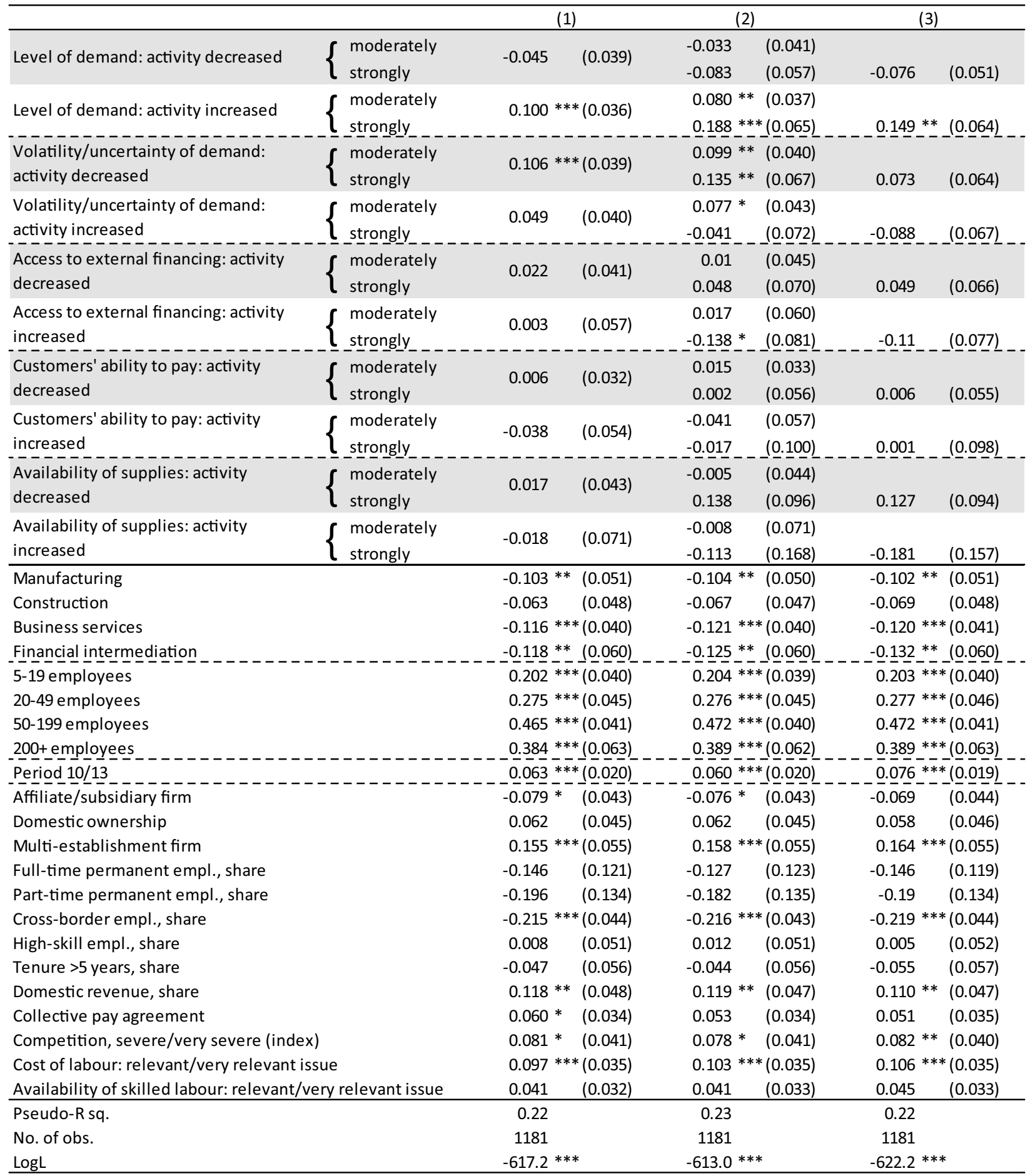

Note: In column (1) moderate and strong negative (positive) shocks are pooled into a single dummy variable, while in column (2), they enter separately. Column ( 3 ) only considers strong negative (positive) shocks. Clustered standard errors in (). The coefficients denote unweighted average marginal effects. ${ }^{* * *}$ ** and * indicate significance at the $1 \%, 5 \%$ and $10 \%$ level, respectively. Base category is trade, 1-4 employees, in 2008-2009, mainly foreign ownership, single-establishment. Excludes firms providing partial information on ALMP use for either sub-period 


\subsection{Robustness of estimates}

We estimated alternative specifications to check the robustness of the baseline results. First, the baseline specification includes all firms regardless of having or not having hired during the sample period. This could bias our estimates, as these firms could not have used ALMPs. Unfortunately, the survey does not include direct information on hiring. As a proxy, we can use information on the tenure structure of firms in 2013 or focus only on firms that grew in terms of employment. Hence, we estimated the baseline model restricted to firms that had less than $100 \%$ of their workforce with tenure of 5 or more years at the end of 2013 (Table 6). The coefficient estimates of the restricted model are largely unchanged suggesting that including firms that did not hire does not drive the overall results. There are few differences: being a subsidiary or affiliated firm does not significantly affect ALMP use, nor does facing severe competition. However, reporting problems sourcing skilled labour significantly increases ALMP use in the restricted model. This result may be linked to the experience gained during the actual hiring process. Alternatively, we consider growing firms only. We estimated a separate logit regression for those firms that had a positive net change in employment over 2008-13. The demand-related effects are confirmed (see Table 7). A strong demand-driven increase in activity raises the probability of using ALMPs. In contrast to the overall sample, demand volatility/uncertainty induced decline in activity does not have a significant impact on ALMP use for growing firms. Hence demand uncertainty operates differently for growing and non-growing firms: for firms with net employment creation over 2008-13, ALMP use is related to favourable conditions in the level or the volatility of demand.

Second, all standard errors in Table 3 were clustered to allow the error term for each firm to be correlated across the two sub-periods. However, we additionally estimated a random effects logit model. Again, the importance of demand-related factors is confirmed. In addition, in specifications (2) and (3), a strong reduction of activity due to a fall in demand, and in specification (3) also due demand volatility, is found to reduce ALMP use. In addition, we considered separating both sub-periods, at the expense of reducing the samples size considerably. Still, the positive effect of the demand level is confirmed for both sub-periods individually. In sub-period 2008-2009, in addition, ALMP use is reduced if firms' activity is negatively affected by demand. ${ }^{16}$

Last, we estimated the baseline regression separately for individual measures (Table 8, Appendix 2). Focussing on demand-related factors, the most significant and robust finding is that participation in apprenticeship subsidies and the employment initiation contract is more likely among firms who saw their activity increase due to favourable demand conditions. These two ALMPs targeting young jobseekers may be driving baseline results. Participation in financial aid for older/long-term unemployed and re-employment support, for which extensive margin rose sizeably, appear to be associated with few of the shocks considered. Furthermore, the share of crossborder workers is a robust predictor of lower ALMP use across measures. The marginal effect is negative and statistically significant for all individual measures. A higher share of temporary employees is associated with higher re-employment support use. Domestic orientation affects most individual ALMP measures. What differs across measures is whether it is domestic headquarter, ownership or revenue share that drive the result. A larger share of high-skill employees tends to increase use of apprenticeship subsidies, indicating that these firms invest in educating and training their workforce to reach the required productivity level. Labour cost concerns increase use of apprenticeship subsidies, while concerns of availability of skilled labour increase the use of financial aid to hire older/long-term unemployed and tax relief. Severe competition increases the likelihood of using re-employment support and tax relief. Firms with more stable workforce have a significantly lower likelihood of using financial aid to hire older/long-term unemployed, re-employment support and tax relief.

\section{Concluding remarks}

This paper analyses various active labour market support measures by the Luxembourg government. It contributes to the literature on the firm-level determinants of ALMPs and it is the first such study using Luxembourg firm-level data.

The results from survey indicate that about one-third of Luxembourg firms made use of public employment support measures between 2008 and 2013. During the crisis, use of active labour market policy measures increased economy-wide both through the extensive margin (more firms) and the intensive margin (more measures per firm). The likelihood that a firm participated in these measures is linked to demand-driven increases in activity, firm size, domestic orientation, being a multi-establishment firm, facing severe competition and concerns about labour costs. Concerns about unavailability of skilled labour, collective pay agreements and the (in-)stability of the workforce are relevant in particular subsamples or specifications for individual ALMP measures. Our

\footnotetext{
${ }^{16}$ Results for the two sub-periods and random effects model are available upon request.
} 
results largely confirm results obtained by Bellmann and Stephan (2014) for German establishment data.

This is only a first step to understand the ALMP use by firms in Luxembourg and eventually evaluate the effectiveness of ALMPs. Future research needs to employ more granular data, such as employee-employer linked data combined with individual ALMP use. Many policy relevant questions could be addressed with these data. One could analyse whether job matches are retained after the subsidies have run out. In other words, do firms use the subsidies to permanently hire employees or are the subsidies mainly used to recurrently hire temporary workers without the prospect of conversion into a permanent job. One could also compare labour market outcomes of ALMP participants to nonparticipants to assess the effectiveness of ALMP participation, as was for example done by Bia et al. (2018) with respect to the effectiveness of language training programmes in Luxembourg. Last but not least, the benefits of ALMPs programmes need to be weighed against the respective costs.

\section{Acknowledgements}

This analysis was conducted as part of the Eurosystem Wage Dynamics Network (WDN) and while Konstantinos Efstathiou was with the Banque centrale du

Luxembourg. We would like to thank Jean Ries and Pierre Gramme (both

ADEM) and Mike Hartmann from STATEC for their very valuable help. We would like to thank two anonymous referees, BCL colleagues, internal and WDN seminar participants and participants at the workshop on "Subjective Survey Data in Labour Market Research" at the Institut für Arbeitsrecht und Arbeitsbeziehungen in der Europäischen Union (IAAEU) for their constructive comments. We are particularly grateful to Paolo Guarda for his detailed comments and suggestions.

This paper should not be reported as representing the views of the BCL or the Eurosystem. The views expressed are those of the authors and may not be shared by other research staff or policymakers in the $\mathrm{BCL}$ or the Eurosystem.

\section{Authors' contributions}

The manuscript is a joint work of the four coauthors. All authors read and approved the final manuscript.

\section{Funding}

None.

Availability of data and materials

Access to the data can be requested via the following link: https://www.ecb. europa.eu/pub/economic-research/research-networks/html/researcher_wdn. en.html

\section{Competing interests}

The authors declare that they have no competing interests.

\section{Author details}

${ }^{1}$ Economics and Research Department, Banque Centrale du Luxembourg, 2, Boulevard Royal, 2983 Luxembourg, Luxembourg. ${ }^{2}$ Bruegel, Brussels, Belgium.

\section{Appendix 1: Variables definition and summary statistics}

See Tables 4 and 5 . 
Table 4 Variables definition and summary statistics (economic shocks)

\begin{tabular}{|c|c|c|c|c|}
\hline \multirow{2}{*}{ Description: 1 if factor } & \multirow[b]{2}{*}{ firms' activity } & & \multirow{2}{*}{$\mathrm{N}$} & \multirow[t]{2}{*}{ Mean } \\
\hline & & $\ldots$ in $t, 0$ otherwise & & \\
\hline \multirow[t]{6}{*}{ Level of demand: } & Decreased & & 1316 & 0.34 \\
\hline & & ...moderately & 1316 & 0.21 \\
\hline & & ...strongly & 1316 & 0.13 \\
\hline & Increased & & 1316 & 0.32 \\
\hline & & ...moderately & 1316 & 0.27 \\
\hline & & ...strongly & 1316 & 0.05 \\
\hline \multirow[t]{6}{*}{ Volatility/uncertainty of demand: } & Decreased & & 1314 & 0.28 \\
\hline & & ...moderately & 1314 & 0.20 \\
\hline & & ...strongly & 1314 & 0.08 \\
\hline & Increased & & 1314 & 0.18 \\
\hline & & ...moderately & 1314 & 0.15 \\
\hline & & ...strongly & 1314 & 0.03 \\
\hline \multirow[t]{6}{*}{ Access to external financing: } & Decreased & & 1308 & 0.18 \\
\hline & & ...moderately & 1308 & 0.12 \\
\hline & & ...strongly & 1308 & 0.06 \\
\hline & Increased & & 1308 & 0.07 \\
\hline & & ...moderately & 1308 & 0.05 \\
\hline & & ...strongly & 1308 & 0.01 \\
\hline \multirow[t]{6}{*}{ Customers'ability to pay: } & Decreased & & 1314 & 0.32 \\
\hline & & ...moderately & 1314 & 0.25 \\
\hline & & ...strongly & 1314 & 0.08 \\
\hline & Increased & & 1314 & 0.08 \\
\hline & & ...moderately & 1314 & 0.06 \\
\hline & & ...strongly & 1314 & 0.02 \\
\hline \multirow[t]{6}{*}{ Availability of supplies: } & Decreased & & 1315 & 0.10 \\
\hline & & ...moderately & 1315 & 0.08 \\
\hline & & ...strongly & 1315 & 0.02 \\
\hline & Increased & & 1315 & 0.05 \\
\hline & & ...moderately & 1315 & 0.05 \\
\hline & & ...strongly & 1315 & 0.00 \\
\hline
\end{tabular}


Table 5 Variables definition and summary statistics

\begin{tabular}{|c|c|c|c|}
\hline Variable & Description & $\mathbf{N}$ & Mean \\
\hline Benefit from ALMP & Discrete; 1 if benefited form any ALMP in t, 0 otherwise & 1293 & 0.43 \\
\hline Applied for STW & Discrete; 1 if applied for STW in t, 0 otherwise & 1312 & 0.04 \\
\hline Manufacturing & Discrete; 1 if firm belongs to NACE code C, 0 otherwise & 1348 & 0.11 \\
\hline Construction & Discrete; 1 if firm belongs to NACE code F, 0 otherwise & 1348 & 0.22 \\
\hline Business services & Discrete; 1 if firm belongs to NACE codes $H, I, J, L, M$ or $N, 0$ otherwise & 1348 & 0.30 \\
\hline Financial intermediation & Discrete; 1 if firm belongs to NACE code $K, 0$ otherwise & 1348 & 0.13 \\
\hline 5-19 employees & Discrete; 1 if firm had 5-19 employees at the end of 2013, 0 otherwise & 1348 & 0.35 \\
\hline 20-49 employees & Discrete; 1 if firm had 20-49 employees at the end of 2013, 0 otherwise & 1348 & 0.25 \\
\hline 50-199 employees & Discrete; 1 if firm had 50-199 employees at the end of 2013, 0 otherwise & 1348 & 0.14 \\
\hline $200+$ employees & Discrete; 1 if firm had 200 employees or more at the end of 2013, 0 otherwise & 1348 & 0.05 \\
\hline Period 10/13 & Discrete; 1 if $\mathrm{t}$ is 2010/13, 0 otherwise & 1348 & 0.50 \\
\hline Affiliate/subsidiary firm & Discrete; 1 if firm was a subsidiary/affiliate at the end of 2013, 0 otherwise & 1338 & 0.28 \\
\hline Domestic ownership & Discrete; 1 if the firm's ownership was mainly domestic at the end of 2013, 0 otherwise & 1336 & 0.75 \\
\hline Multi-establishment firm & Discrete; 1 if the firm was a multiple-establishment firm at the end of 2013, 0 otherwise & 1346 & 0.14 \\
\hline FT perm. empl., share & Continuous; permanent full-time employees as a share of total employees at the end of 2007 & 1274 & 0.87 \\
\hline PT perm. empl., share & Continuous; permanent part-time employees as a share of total employees at the end of 2007 & 1274 & 0.11 \\
\hline Cross-border empl., share & Continuous; cross-border employees as a share of total employees at the end of 2007 & 1272 & 0.51 \\
\hline High-skill empl., share & $\begin{array}{l}\text { Continuous; employees belonging to ISCO classes 1, 2, 3, } 7 \text { or } 8 \text { as a share of total employees at the } \\
\text { end of } 2013\end{array}$ & 1330 & 0.58 \\
\hline Tenure $>5$ years, share & Continuous; employees with job tenure exceeding 5 years as a share of total employees at the end of 2013 & 1338 & 0.60 \\
\hline Domestic revenue, share & Continuous; sales in the domestic market as a share of total sales in 2013 & 1340 & 0.71 \\
\hline Collective pay agreement & $\begin{array}{l}\text { Discrete; } 1 \text { if the proportion of employees covered in } 2013 \text { by any collective pay agreement is greater } \\
\text { than 0, } 0 \text { otherwise }\end{array}$ & 1316 & 0.45 \\
\hline $\begin{array}{l}\text { Competition, severe/very } \\
\text { severe (index) }\end{array}$ & $\begin{array}{l}\text { Continuous, weighted average; } 1=\text { weak, } 2=\text { moderate, } 3=\text { severe, } 4=\text { very severe, weighted by the } \\
\text { respective market share in } 2013\end{array}$ & 1338 & 0.78 \\
\hline $\begin{array}{l}\text { Cost of labour: relevant/very } \\
\text { relevant issue }\end{array}$ & Discrete; 1 if cost of labour was a relevant/very relevant issue for the firm in t, 0 otherwise & 1284 & 0.61 \\
\hline $\begin{array}{l}\text { Availability of skilled labour: } \\
\text { relevant/very relevant issue }\end{array}$ & $\begin{array}{l}\text { Discrete; } 1 \text { if availability of skilled staff or experienced managers was a relevant/very relevant issue for } \\
\text { the firm in t, } 0 \text { otherwise }\end{array}$ & 1298 & 0.60 \\
\hline $\begin{array}{l}\text { Relevant hiring obstacle: hiring } \\
\text { costs }\end{array}$ & $\begin{array}{l}\text { Discrete; } 1 \text { if firing costs were a relevant/very relevant obstacle in hiring workers with a permanent, } \\
\text { open-ended contracts at the end of 2013, } 0 \text { otherwise }\end{array}$ & 1312 & 0.34 \\
\hline $\begin{array}{l}\text { Relevant hiring obstacle: firing } \\
\text { costs }\end{array}$ & $\begin{array}{l}\text { Discrete; } 1 \text { if hiring costs were a relevant/very relevant obstacle in hiring workers with a permanent, } \\
\text { open-ended contracts at the end of 2013,0 otherwise }\end{array}$ & 1318 & 0.47 \\
\hline $\begin{array}{l}\text { Relevant hiring obstacle: } \\
\text { skilled labour }\end{array}$ & $\begin{array}{l}\text { Discrete; } 1 \text { if insufficient availability of labour with the required skills was a relevant/very relevant obsta- } \\
\text { cle in hiring workers with a permanent, open-ended contracts at the end of 2013, } 0 \text { otherwise }\end{array}$ & 1320 & 0.65 \\
\hline
\end{tabular}

\section{Appendix 2: Robustness checks} See Tables 6, 7 and 8 . 
Table 6 Pooled logit estimates for probability of using ALMPs (firms having hired and retained employees until 2013)

\begin{tabular}{|c|c|c|c|c|c|c|}
\hline \multirow[b]{2}{*}{ Level of demand: activity decreased } & \multicolumn{2}{|l|}{ (1) } & \multicolumn{2}{|c|}{ (2) } & \multicolumn{2}{|c|}{ (3) } \\
\hline & -0.064 & $(0.044)$ & $\begin{array}{l}-0.055 \\
-0.081\end{array}$ & $\begin{array}{l}(0.046) \\
(0.063)\end{array}$ & -0.064 & $(0.057)$ \\
\hline Level of demand: activity increased & $0.085 * * *$ & k $(0.040)$ & $\begin{array}{l}0.066 \\
0.173 * *\end{array}$ & $\begin{array}{r}(0.041) \\
*(0.065) \\
\end{array}$ & $0.143 * *$ & $(0.065)$ \\
\hline $\begin{array}{l}\text { Volatility/uncertainty of demand: } \\
\text { activity decreased }\end{array}$ & $0.107^{* *}$ & $(0.043)$ & $\begin{array}{l}0.103 * * \\
0.120 *\end{array}$ & $\begin{array}{l}(0.044) \\
(0.072)\end{array}$ & 0.058 & $(0.070)$ \\
\hline $\begin{array}{l}\text { Volatility/uncertainty of demand: } \\
\text { activity increased }\end{array}$ & 0.052 & $(0.045)$ & $\begin{array}{c}0.081 * \\
-0.061 \\
----\end{array}$ & $\begin{array}{r}(0.047) \\
(\underline{0} .080)\end{array}$ & -0.106 & $(\underline{0} .074)$ \\
\hline $\begin{array}{l}\text { Access to external financing: activity } \\
\text { decreased }\end{array}$ & 0.033 & $(0.047)$ & $\begin{array}{l}0.034 \\
0.039\end{array}$ & $\begin{array}{l}(0.052) \\
(0.078)\end{array}$ & 0.034 & $(0.075)$ \\
\hline $\begin{array}{l}\text { Access to external financing: activity } \\
\text { increased }\end{array}$ & -0.007 & $(0.061)$ & $\begin{array}{r}0.014 \\
-0.135 \\
-\end{array}$ & $\begin{array}{r}(0.064) \\
(-0.094) \\
\end{array}$ & -0.11 & $(\underline{0} .087)$ \\
\hline $\begin{array}{l}\text { Customers' ability to pay: activity } \\
\text { decreased }\end{array}$ & 0.009 & $(0.036)$ & $\begin{array}{r}0.021 \\
-0.013\end{array}$ & $\begin{array}{l}(0.038) \\
(0.062)\end{array}$ & -0.011 & $(0.061)$ \\
\hline $\begin{array}{l}\text { Customers' ability to pay: activity } \\
\text { increased }\end{array}$ & -0.029 & $(0.061)$ & $\begin{array}{l}-0.022 \\
-0.056\end{array}$ & $\begin{array}{l}(0.065) \\
(0.109)\end{array}$ & -0.043 & (0.107) \\
\hline $\begin{array}{l}\text { Availability of supplies: activity } \\
\text { decreased }\end{array}$ & -0.007 & $(0.049)$ & 0.064 & $\begin{array}{l}(0.051) \\
(0.099)\end{array}$ & 0.055 & $(0.096)$ \\
\hline $\begin{array}{l}\text { Availability of supplies: activity } \\
\text { increased }\end{array}$ & -0.026 & $(0.080)$ & $\begin{array}{l}-0.022 \\
-0.098 \\
\end{array}$ & $\begin{array}{l}(0.080) \\
(0.209) \\
\end{array}$ & -0.17 & $(0.209)$ \\
\hline Manufacturing & $-0.118 * *$ & $(0.059)$ & $-0.120 * *$ & (0.059) & $-0.119 * *$ & $(0.059)$ \\
\hline Construction & -0.073 & $(0.056)$ & -0.077 & $(0.055)$ & -0.079 & $(0.056)$ \\
\hline Business services & $-0.134 * * *$ & ${ }^{k}(0.048)$ & $-0.141 * *$ & $*(0.048)$ & $-0.139 * *$ & ${ }^{*}(0.049)$ \\
\hline Financial intermediation & $-0.165 * *$ & $-(0.067)$ & $-0.172 * *$ & *(0.066) & $-0.183^{* *}$ & ${ }^{k}(\underline{0} .066)$ \\
\hline 5-19 employees & $0.214 * *$ & $(0.050)$ & $0.214 * *$ & $*(0.050)$ & $0.215^{* *}$ & ${ }^{*}(0.051)$ \\
\hline 20-49 employees & $0.269 * * *$ & ( $(0.053)$ & $0.266^{* *}$ & $*(0.054)$ & $0.271 * *$ & ${ }^{*}(0.055)$ \\
\hline 50-199 employees & $0.459 * * *$ & ( $(0.042)$ & $0.463 * *$ & $*(0.042)$ & $0.465 * *$ & ${ }^{*}(0.042)$ \\
\hline 200+employees & $0.385^{* * *}$ & $(0.063)$ & $0.389 * *$ & *( & $0.390 * *$ & ${ }^{*}(0.062)$ \\
\hline Period $10 / 13$ & $0.078^{* *}$ & $(0.023)$ & $0.076 * *$ & $*(0.023)$ & $0.093 * *$ & $(0.022)$ \\
\hline Affiliate/subsidiary firm & -0.075 & $(0.049)$ & -0.072 & $(0.049)$ & -0.069 & $(0.050)$ \\
\hline Domestic ownership & 0.051 & $(0.052)$ & 0.054 & $(0.052)$ & 0.046 & $(0.052)$ \\
\hline Multi-establishment firm & $0.137^{* *}$ & $(0.058)$ & $0.139 * *$ & $(0.058)$ & $0.143 * *$ & $(0.058)$ \\
\hline Full-time permanent empl., share & -0.183 & $(0.130)$ & -0.163 & $(0.134)$ & -0.187 & $(0.131)$ \\
\hline Part-time permanent empl., share & -0.255 & $(0.156)$ & -0.243 & $(0.157)$ & -0.256 & $(0.158)$ \\
\hline Cross-border empl., share & $-0.226 * * *$ & $(0.052)$ & $-0.224 * *$ & $*(0.051)$ & $-0.233 * *$ & ${ }^{k}(0.052)$ \\
\hline High-skill empl., share & 0.013 & $(0.059)$ & 0.019 & $(0.060)$ & 0.012 & $(0.060)$ \\
\hline Tenure $>5$ years, share & -0.016 & $(0.073)$ & -0.013 & $(0.073)$ & -0.024 & $(0.074)$ \\
\hline Domestic revenue, share & $0.147 * * *$ & $(0.054)$ & $0.146 * *$ & $*(0.054)$ & $0.132 * *$ & $(0.054)$ \\
\hline Collective pay agreement & 0.053 & $(0.039)$ & 0.046 & $(0.039)$ & 0.046 & $(0.040)$ \\
\hline Competition, severe/very severe (index) & 0.060 & $(0.047)$ & 0.057 & $(0.046)$ & 0.06 & (0.046) \\
\hline Cost of labour: relevant/very relevant issue & $0.086 * *$ & (0.039) & $0.093 * *$ & $(0.040)$ & $0.096 * *$ & $(0.039)$ \\
\hline Availability of skilled labour: relevant/very relevant issue & $0.065 *$ & $(0.037)$ & $0.067 *$ & $(0.038)$ & $0.071 *$ & $(0.037)$ \\
\hline Pseudo-R sq. & 0.19 & & 0.2 & & 0.19 & \\
\hline No. of obs. & 993 & & 993 & & 993 & \\
\hline LogL & $-551.7^{* * *}$ & & $-548.7^{* *}$ & & $-556.0 * *$ & \\
\hline
\end{tabular}

See Table 3 
Table 7 Pooled logit estimates for probability of using ALMPs (firms growing in employment between 2008 and 2013)

\begin{tabular}{|c|c|c|c|c|c|c|}
\hline \multirow[b]{2}{*}{ Level of demand: activity decreased } & \multicolumn{2}{|c|}{ (1) } & \multicolumn{2}{|c|}{$(2)$} & \multicolumn{2}{|c|}{ (3) } \\
\hline & -0.010 & $(0.057)$ & $\begin{array}{r}0.002 \\
-0.079\end{array}$ & $\begin{array}{l}(0.059) \\
(0.080)\end{array}$ & -0.062 & $(0.071)$ \\
\hline Level of demand: activity increased & 0.072 & $(0.046)$ & $\begin{array}{l}0.037 \\
0.211 * *\end{array}$ & $\begin{array}{l}(0.048) \\
(0.068)\end{array}$ & $0.180 *$ & $*(0.066)$ \\
\hline $\begin{array}{l}\text { Volatility/uncertainty of demand: } \\
\text { activity decreased }\end{array}$ & 0.080 & $(0.058)$ & 0.071 & $\begin{array}{l}(0.061) \\
(0.100)\end{array}$ & 0.109 & $(0.097)$ \\
\hline $\begin{array}{l}\text { Volatility/uncertainty of demand: } \\
\text { activity increased }\end{array}$ & 0.055 & $(0.049)$ & $\begin{array}{l}0.099 * \\
-0.103 \\
--1--\end{array}$ & $\begin{array}{l}(0.052) \\
(0.089)\end{array}$ & -0.130 & $(0.083)$ \\
\hline $\begin{array}{l}\text { Access to external financing: activity } \\
\text { decreased }\end{array}$ & 0.074 & $(0.058)$ & $\begin{array}{l}0.061 \\
0.127\end{array}$ & $\begin{array}{l}(0.061) \\
(0.112)\end{array}$ & 0.124 & $(0.109)$ \\
\hline $\begin{array}{l}\text { Access to external financing: activity } \\
\text { increased }\end{array}$ & -0.018 & $(0.071)$ & $\begin{array}{l}-0.009 \\
-0.214 * *\end{array}$ & $\begin{array}{l}(0.073) \\
(\underline{0}-084)\end{array}$ & $-0.168 *$ & $(0.083)$ \\
\hline $\begin{array}{l}\text { Customers' ability to pay: activity } \\
\text { decreased }\end{array}$ & 0.013 & $(0.046)$ & $\begin{array}{l}0.034 \\
-0.035\end{array}$ & $\begin{array}{l}(0.047) \\
(0.080)\end{array}$ & -0.036 & $(0.073)$ \\
\hline $\begin{array}{l}\text { Customers' ability to pay: activity } \\
\text { increased }\end{array}$ & -0.032 & $(0.076)$ & $\begin{array}{r}-0.043 \\
0.051 \\
-\end{array}$ & $\begin{array}{l}(0.080) \\
(\underline{0.128})\end{array}$ & 0.049 & $(0.128)$ \\
\hline $\begin{array}{l}\text { Availability of supplies: activity } \\
\text { decreased }\end{array}$ & 0.065 & $(0.077)$ & 0.028 & $\begin{array}{l}(0.084) \\
(0.101)\end{array}$ & $0.187 *$ & $(0.103)$ \\
\hline $\begin{array}{l}\text { Availability of supplies: activity } \\
\text { increased }\end{array}$ & 0.064 & $(0.093)$ & $\begin{array}{r}0.097 \\
-0.126 \\
\end{array}$ & $\begin{array}{l}(0.092) \\
(0.190) \\
\end{array}$ & -0.199 & $(0.172)$ \\
\hline Manufacturing & -0.091 & $(0.075)$ & -0.102 & $(0.072)$ & -0.094 & $(0.073)$ \\
\hline Construction & $-0.144 *$ & $(0.063)$ & $-0.160 * *$ & (0.059) & $-0.146 * *$ & $(0.061)$ \\
\hline Business services & $-0.137 *$ & $(0.057)$ & $-0.145 * *$ & $(0.057)$ & $-0.141 * *$ & $(0.059)$ \\
\hline Financial intermediation & $-0.164 *$ & $(\underline{0.083})$ & $-0.170 * *$ & $(0.081)$ & $-0.188 * *$ & $(0.080)$ \\
\hline 5-19 employees & $0.158 *$ & $(0.081)$ & $0.167 * *$ & $(0.076)$ & $0.184 * *$ & $(0.077)$ \\
\hline 20-49 employees & $0.220 *$ & $*(0.085)$ & $0.226 * * ;$ & $(0.082)$ & $0.238 * *$ & $*(0.083)$ \\
\hline 50-199 employees & $0.418 *$ & $*(0.071)$ & $0.429 * * ;$ & $(0.066)$ & $0.443 * *$ & $*(0.065)$ \\
\hline $200+$ employees & $-0.296 *$ & $*(0.102)$ & $-0.302 * *$ & $=\left(\begin{array}{ll}0.101) \\
(0.028)\end{array}\right.$ & $0.313 * *$ & ${ }^{*}(0.101)$ \\
\hline Affiliate/subsidiary firm & -0.09 & $(0.059)$ & -0.091 & $(0.059)$ & -0.092 & $(0.060)$ \\
\hline Domestic ownership & 0.065 & $(0.059)$ & 0.062 & $(0.058)$ & 0.058 & $(0.058)$ \\
\hline Multi-establishment firm & $0.129 *$ & $(0.069)$ & $0.138 *$ & (0.071) & $0.144 * *$ & $(0.070)$ \\
\hline Full-time permanent empl., share & -0.047 & $(0.156)$ & -0.016 & $(0.158)$ & -0.083 & $(0.164)$ \\
\hline Part-time permanent empl., share & -0.145 & $(0.180)$ & -0.141 & $(0.180)$ & -0.186 & (0.191) \\
\hline Cross-border empl., share & $-0.241 *$ & $*(0.065)$ & $-0.245 * * *$ & $=(0.063)$ & $-0.232 * *$ & $*(0.064)$ \\
\hline High-skill empl., share & -0.02 & $(0.074)$ & -0.01 & $(0.074)$ & -0.008 & $(0.075)$ \\
\hline Tenure $>5$ years, share & -0.131 & $(0.085)$ & -0.123 & $(0.085)$ & -0.127 & $(0.086)$ \\
\hline Domestic revenue, share & $0.181 *$ & $*(0.065)$ & $0.186 * *$ & $(0.065)$ & $0.170 * *$ & $*(0.065)$ \\
\hline Collective pay agreement & $0.121 *$ & $(0.052)$ & $0.108 * *$ & $(0.053)$ & $0.107 * *$ & $(0.051)$ \\
\hline Competition, severe/very severe (index) & 0.002 & $(0.056)$ & -0.002 & $(0.055)$ & 0.008 & $(0.054)$ \\
\hline Cost of labour: relevant/very relevant issue & $0.084 *$ & $(0.048)$ & $0.097 * *$ & $(0.048)$ & $0.096 *$ & $(0.049)$ \\
\hline Availability of skilled labour: relevant/very relevant issue & 0.062 & $(0.046)$ & 0.062 & $(0.046)$ & 0.065 & $(0.045)$ \\
\hline Pseudo-R sq. & 0.22 & & 0.24 & & 0.23 & \\
\hline No. of obs. & 634 & & 634 & & 634 & \\
\hline LogL & $-339.1 *$ & & $-332.5 * * *$ & & $-338.3 *$ & \\
\hline
\end{tabular}

See Table 3 
Table 8 Pooled logit estimates for probability of using individual ALMP measures

\begin{tabular}{|c|c|c|c|c|c|c|c|c|c|c|c|c|c|c|c|}
\hline & \multicolumn{3}{|c|}{$\begin{array}{l}\text { Financial aid to hire } \\
\text { older/lt. unemployed }\end{array}$} & \multicolumn{3}{|c|}{$\begin{array}{c}\text { Re-employment } \\
\text { support }\end{array}$} & \multicolumn{3}{|c|}{$\begin{array}{c}\text { Tax relief for hiring } \\
\text { unemployed workers }\end{array}$} & \multicolumn{3}{|c|}{ Apprenticeship subsidies } & \multicolumn{3}{|c|}{$\begin{array}{c}\text { Employment initiation } \\
\text { contract }\end{array}$} \\
\hline & (1) & (2) & (3) & (1) & (2) & (3) & (1) & (2) & (3) & (1) & (2) & (3) & (1) & (2) & (3) \\
\hline Level of demand : activity decreased & & & & & & & & & & & $-*$ & & & & \\
\hline Level of demand : activity increased & & & & & & & & & & $+* *$ & $+* * *$ & $+* *$ & $+*$ & $+* *$ & $+^{*}$ \\
\hline $\begin{array}{l}\text { Volatility/uncertainty of demand : activity } \\
\text { decreased }\end{array}$ & $+* *$ & $+*$ & & $+*$ & $+*$ & & & & & $+* *$ & $+* *$ & & & & $-* *$ \\
\hline $\begin{array}{l}\text { Volatility/uncertainty of demand : activity } \\
\text { increased }\end{array}$ & $+* * *$ & $+* * *$ & & & & & & & & & & & & & \\
\hline Access to external financing : activity decreased $\left\{\begin{array}{l}\text { moderately } \\
\text { strongly }\end{array}\right.$ & & & & & & & & & & & $+*$ & & & & \\
\hline Access to external financing : activity increased $\left\{\begin{array}{l}\text { moderately } \\
\text { strongly }\end{array}\right.$ & & & & $-*$ & & & & & & & $-* * *$ & $-* * *$ & & & \\
\hline Customers' ability to pay : activity decreased $\quad\left\{\begin{array}{l}\text { moderately } \\
\text { strongly }\end{array}\right.$ & & & & & & & & & & & ** & $* *$ & & & \\
\hline Customers' ability to pay : activity increased $\quad\left\{\begin{array}{l}\text { moderately } \\
\text { strongly }\end{array}\right.$ & & & & & & & & & & & & & & & \\
\hline Availability of supplies : activity decreased & & & & & & & & $+* *$ & $+*$ & & & & & & \\
\hline Availability of supplies : activity increased & & & & & & & & & & & & & $-*$ & $-* * *$ & \\
\hline Manufacturing & & & & & & & & $-*$ & & & $-^{*}$ & & & & \\
\hline Construction & & & & $-* *$ & $-* *$ & $-* *$ & $-*$ & $-* *$ & $-*$ & & & & $-*$ & & $-*$ \\
\hline Business services & & & & & & & & & & $-* * *$ & $-* * *$ & $-* * *$ & $-*$ & $-*$ & \\
\hline Financial intermediation & & & & & & & & & & $-* * *$ & $-* * *$ & $-* * *$ & & & \\
\hline 5-19 employees & $+* * *$ & $+* * *$ & $+* * *$ & $+* * *$ & $+* * *$ & $+* * *$ & $+* * *$ & $+* * *$ & $+* * *$ & $+* * *$ & $+* * *$ & $+* * *$ & & & \\
\hline 20-49 employees & $+* * *$ & $+* * *$ & $+* * *$ & $+* * *$ & $+* * *$ & $+* * *$ & $+* * *$ & $+* * *$ & $+* * *$ & $+* * *$ & $+* * *$ & $+* * *$ & $+* *$ & $+*$ & $+*$ \\
\hline 50-199 employees & $+* * *$ & $+* * *$ & $+* * *$ & $+* * *$ & $+* * *$ & $+* * *$ & $+* * *$ & $+* * *$ & $+* * *$ & $+* * *$ & $+* * *$ & $+* * *$ & $+* * *$ & $+* *$ & $+* *$ \\
\hline $200+$ employees & $+* * *$ & $+* * *$ & $+* * *$ & $+* * *$ & $+* * *$ & $+* * *$ & $+* * *$ & $+* * *$ & $+* * *$ & $+* * *$ & $+* * *$ & $+* * *$ & $+* * *$ & $+* * *$ & $+* * *$ \\
\hline Period 10/13 & $+* * *$ & $+* * *$ & $+* * *$ & $+* * *$ & $+* * *$ & $+* * *$ & $+*$ & $+*$ & $+* *$ & & & $+* *$ & $+*$ & & $+*$ \\
\hline Affiliate/subsidiary firm & & & & & & & & & & $-* * *$ & $-* * *$ & $-* * *$ & & & \\
\hline Domestic ownership & $+*$ & $+*$ & & & & & $+* * *$ & $+* * *$ & $+* * *$ & & & & $+* *$ & $+* *$ & $+* *$ \\
\hline Multi-establishment firm & & & & & & & & & & $+* * *$ & $+* * *$ & $+* * *$ & & & \\
\hline Full-time permanent empl., share & & & & $-* *$ & $-* *$ & $-* *$ & & & & & & & & & \\
\hline Part-time permanent empl., share & & & & $-*$ & $-*$ & $-*$ & & & & & & & & & \\
\hline Cross-border empl., share & $-* * *$ & $-* * *$ & $-* * *$ & $-* *$ & $-* *$ & $-* * *$ & $-* * *$ & $-* * *$ & $-* * *$ & $-* * *$ & $-* * *$ & $-* * *$ & $-* * *$ & $-* * *$ & $-* * *$ \\
\hline High-skill empl., share & & & & & & & & & & $+*$ & $+*$ & $+*$ & & & \\
\hline Tenure $>5$ years, share & $-*$ & $-*$ & $-{ }^{* *}$ & $-*$ & $-* *$ & $-* *$ & $-* *$ & - ** & - ** & & & & & & \\
\hline Domestic revenue, share & & & & & & & & & & $+^{*}$ & & & $+* *$ & $+* *$ & $+* *$ \\
\hline Collective pay agreement & & & & & & & & & & $+* *$ & $+* *$ & $+* *$ & & & \\
\hline Competition, severe/very severe (index) & & & & $+*$ & $+*$ & $+* *$ & $+* *$ & $+* *$ & $+* *$ & & & & & & \\
\hline Cost of labour: relevant/very relevant issue & & & & & & & & & & $+* * *$ & $+* * *$ & $+* * *$ & & & \\
\hline Availability of skilled labour: relevant/very relevant issue & $+* *$ & $+*$ & $+*$ & & & & $+* *$ & $+* *$ & $+* *$ & & & & & & \\
\hline Pseudo-R sq. & 0.14 & 0.15 & 0.14 & 0.17 & 0.18 & 0.17 & 0.16 & 0.17 & 0.16 & 0.23 & 0.24 & 0.23 & 0.19 & 0.20 & 0.18 \\
\hline No. of obs. & 1181 & 1181 & 1181 & 1181 & 1181 & 1181 & 1181 & 1181 & 1181 & 1181 & 1181 & 1181 & 1181 & 1181 & 1181 \\
\hline LogL & *** & *** & *** & $* * *$ & *** & $* * *$ & $* * *$ & *** & *** & $* * *$ & $* * *$ & *** & *** & $* * *$ & $* * *$ \\
\hline
\end{tabular}

See Table 3

Received: 15 March 2019 Accepted: 26 July 2019

Published online: 18 September 2019

\section{References}

ADEM (Agence pour le développement de l'emploi): Rapport annuel 2014. ADEM, Luxembourg (2015)

Barron, J.M., Mellow, W.: Labor contract formation, search requirements, and use of a public employment service. Econ. Inq. 20, 381-387 (1982)

Barron, J.M., Bishop, J., Dunkelberg, W.C.: Employer search: the interviewing and hiring of new employees. Rev. Econ. Stat. 67(1), 43-52 (1985)

BCL: Le chômage de longue durée, tenants et aboutissants, BCL Bulletin 2015/1, Encadré 2, Central Bank of Luxembourg (2015)

Bellmann, L., Stephan, G.: Which firms use targeted wage subsidies? An empirical note for Germany. J. Labour Market Res. 47, 165-175 (2014)

Bia, M., Flores-Lagunes, A., Mercatanti, A.: Evaluation of langage training programs in Luxembourg using principal stratification. IZA DP 11973 (2018)

Bishop, J.H., Kang, S.: Applying for entitlements: employers and targeted jobs tax credit. J. Policy Anal. Manag. 10(1), 24-45 (1991)

Bishop, J.H., Montgomery, M.: Evidence on firm participation in employment subsidy programs. Ind. Rel. 25, 56-64 (1986)

Calmfors, L.: Active labour market policy and unemployment-a framework for the analysis of crucial design features. OECD Econ. Stud. 22, 1 (1994)

Efstathiou, K., Mathä, T.Y., Veiga, C., Wintr, L.: Short-time work in Luxembourg: evidence from a firm survey. J. Labour Mark. Res. 52(1), 14 (2018)
European Commission. European Semester: Thematic factsheet-Active labour market policies. https://ec.europa.eu/info/sites/info/files/europ ean-semester_thematic-factsheet_active-labour-market-policies_en_0. pdf (2016). Accessed 13 Mar 2019

Gerlach, K., Levine, D., Stephan, G., Struck, O.: Fairness and the employment contract: north American regions versus Germany. Camb. J. Econ. 32, 421-439 (2008)

Gorter, C., Nijkamp, P., Rietveld, P.: Employers' recruitment behaviour and vacancy duration: an empirical analysis for the Dutch labour market. Appl. Econ. 28, 1463-1474 (1996)

Mathä, T.Y., Veiga, C., Wintr, L.: Employment, wages and prices: How did firms adjust during the economic and financial crisis: Evidence from a survey of Luxembourg firms. BCL Working Paper 104, Central Bank of Luxembourg (2016)

Roger, M., Zamora, P.: Hiring young, unskilled workers on subsidized openended contracts: a good integration programme? Oxford Rev. Econ. Policy 27(2), 380-396 (2011)

Van Ours, J.C.: Matching unemployed and vacancies at the public employment office. Empir. Econ. 19(1), 37-54 (1994)

Van Ours, J.C., Ridder, G.: Vacancy durations: search or selection? Oxford Bull. Econ. Stat. 55(2), 187-198 (1993)

Van Polanen Petel, V., Hu T., De Koning J., Van der Veen C.: Werkgelegenheidseffecten van de SPAK en de VLW, Nederlands Economisch Instituut, Rotterdam (1999)

Welters, R., Muysken, J.: Employer search and employment subsidies. Appl. Econ. 38(12), 1435-1448 (2006) 
Zanardelli, M., Brosius, J., Clément, F.: Evaluation de l'efficacité des mesures en faveur de l'emploi au Luxembourg. Rapport final pour le compte de I'ORPE et du Ministère du Travail et de l'Emploi. CEPS/INSTEAD (2006)

\section{Publisher's Note}

Springer Nature remains neutral with regard to jurisdictional claims in published maps and institutional affiliations. 